\title{
Article
}

\section{Truth and Closure in Cyprus: An Assessment of the Committee on Missing Persons}

\author{
Hadjigeorgiou, Athanasia \\ Available at http://clok.uclan.ac.uk/37504/ \\ Hadjigeorgiou, Athanasia ORCID: 0000-0002-7324-9689 (2021) Truth and \\ Closure in Cyprus: An Assessment of the Committee on Missing Persons. Israel \\ Law Review . ISSN 0021-2237
}

It is advisable to refer to the publisher's version if you intend to cite from the work. http://dx.doi.org/10.1017/S0021223721000121

For more information about UCLan's research in this area go to http://www.uclan.ac.uk/researchgroups/ and search for < name of research Group>.

For information about Research generally at UCLan please go to http://www.uclan.ac.uk/research/

All outputs in CLoK are protected by Intellectual Property Rights law, including Copyright law. Copyright, IPR and Moral Rights for the works on this site are retained by the individual authors and/or other copyright owners. Terms and conditions for use of this material are defined in the policies page.

\section{CLoK}

Central Lancashire online Knowledge www.clok.uclan.ac.uk

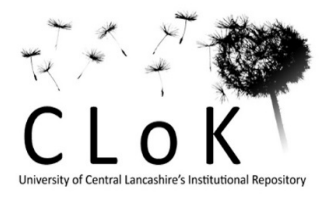




\title{
Truth and Closure in Cyprus:
}

\section{An Assessment of the Committee on Missing Persons}

\section{Pre-publication draft, accepted for publication in Israel Law Review}

\author{
Nasia Hadjigeorgiou \\ Assistant Professor in Transitional Justice and Human Rights \\ University of Central Lancashire (Cyprus)
}

\section{Acknowledgements}

The project that this publication forms a part of, is funded by the International Peace Research Association (IPRA) Foundation. Special thanks to Tasos Andreou, Fezile Osum and Başak Ekenoglu for their research assistance. I am also grateful to Dr Grażyna Baranowska, Ximena Londono and the participants of the 15th Annual Minerva/ICRC Conference on International Humanitarian Law Indirect Victims of Conflict for providing comments to a previous draft of this article.

\begin{abstract}
There are two key limitations to the literature that explores the relationship between truth and closure in post-violence societies. The first is that this relationship has mostly been assessed as part of a larger debate focusing on the links between the truth and the seemingly related concept of reconciliation. The second is that to the extent the literature has dealt with the connections between truth and closure as such, it has almost exclusively focused on the operations and effects of courts and truth commissions. The article addresses both limitations by examining the relationship between truth and closure through the prism of a different institution, the Committee on Missing Persons in Cyprus. Relying on 34 in-depth interviews with key stakeholders, including relatives of missing persons on the island, it argues that the Committee's delivery of the truth has promoted closure in three distinct ways. At the same time, it acknowledges that the way in which and the type of truth that is being delivered can have detrimental consequences to the promotion of closure. A short video summarising the findings of this paper is available here.
\end{abstract}

Keywords: Truth, Closure, Committee on Missing Persons (CMP), Cyprus

\section{INTRODUCTION}

This article examines two oft-discussed concepts of the transitional justice literature - truth and closure - in a fresh light. It argues that they have often been explored as part of a larger debate that focuses on reconciliation, but that doing so hides more than it illuminates. What is important to understand, but is often missing, is whether discovering the truth about a past 
event contributes to a sense of closure, and how exactly this happens, even when the truth does not necessarily also promote reconciliation. The article sheds light on the relationship between the two concepts by focusing on the experiences of the families of those who went missing in Cyprus between 1963 and 1974.

The case study is original in two respects. The first is that although ' $[u]$ ncertainty about the fate of a relative is a harsh reality for countless families around the world', ${ }^{1}$ the problem of missing persons has generally not been a priority item in researchers' or policy makers' agendas. ${ }^{2}$ The second is that when exploring the impact of truth-seeking institutions, most commentators have focused on courts and/or truth commissions because most post-violence societies have relied on these institutions. Cyprus has opted for neither and established instead the Committee on Missing Persons (Committee or CMP). Variations of this institution, tasked with revealing the truth by locating, identifying and returning the remains of missing persons to their families, have also been adopted elsewhere. ${ }^{3}$ The CMP is worth examining however, because it was the first such body to be established, although not the first to become operational. ${ }^{4}$ An assessment of the Committee is also important as it is currently providing training in a range of forensic techniques to scientists from other post-violence societies. ${ }^{5}$

Section 2 briefly describes the state of, and gaps in, the literature on truth and closure and Section 3 provides basic information about the CMP and the Cypriot conflict. Section 4 outlines the methodology that was followed, namely a combination of library-based and empirical research, consisting of 34 interviews with key stakeholders. Finally, Section 5 presents the findings of the research: it acknowledges the closure-inducing effects of the Committee's

\footnotetext{
${ }^{1}$ ICRC, Missing Persons: A Hidden Tragedy (ICRC, 2007), 10.

2 ibid, 4. See also Janine Natalya Clark, 'Missing Persons, Reconciliation and the View from Below: A Case Study of Bosnia-Hercegovina' (2010) 10 Southeast European and Black Sea Studies 425; Monique Crettol et al, 'Establishing Mechanisms to Clarify the Fate and Whereabouts of Missing Persons: A Proposed Humanitarian Approach' (2017) 99 International Review of the Red Cross 589, 597.

${ }^{3} \mathrm{Eg}$, the Argentine Forensic Anthropology Team started operating in 1986; the Missing Persons Institute in Bosnia and Herzegovina was established in 1996; the Forensic Anthropology Foundation of Guatemala was set up in 1997 and the Missing Persons Task Team in South Africa was initiated in 2005. These bodies started work before the CMP became operational (and, in fact, Bosnian and Argentinian expertise was instrumental in making the CMP so), but the humanitarian vision of the CMP was set out in its 1981 Terms of Reference (CMP, 'Terms of Reference: Establishment of the Committee on Missing Persons in Cyprus', available at http://www.cmpcyprus.org/content/terms-reference-and-mandate (CMP Terms of Reference)). To the author's knowledge, no other institution had been set up with this objective before 1981.

${ }^{4}$ Grażyna Baranowska, Rights of Families of Disappeared Persons: How International Bodies Address the Needs of Families of Disappeared Persons in Europe (Intersentia, 2021).

${ }^{5} \mathrm{Eg}$, the CMP has provided training to Iraqi officials. (CMP, 'Partners and Cooperation', available at http://www.cmp-cyprus.org/content/partners-and-cooperation.)
} 
activities, while explaining that the way in which the CMP chose to deliver the truth, coupled with the type of truth it opted to deliver, undermined its overall objective.

\section{HEARING THE TRUTH AND ACHIEVING CLOSURE}

A range of arguments have been proposed about how truth leads to reconciliation. ${ }^{6}$ It has been suggested that the truth promotes the individualisation of guilt in hate-mongering leaders and avoids the labelling of whole groups as collectively responsible $;^{7}$ it sets the basis for an official, authoritative account of past crimes; ${ }^{8}$ or it contributes through criminal accountability processes to the promotion of justice, ${ }^{9}$ which is itself essential for reconciliation. ${ }^{10}$ Among the most frequently articulated arguments, and the starting point of this analysis, is that the truthtelling process empowers victims because it imparts a sense of closure on them, ${ }^{11}$ especially when the harm they have suffered is publicly acknowledged by an official body. ${ }^{12}$ It is through this sense of closure that victims are given the strength and tools to reconcile with past atrocities committed against them or their family members. The idea is that the replication of this process and the achievement of closure on the societal level, eventually promotes reconciliation. ${ }^{13}$

\footnotetext{
${ }^{6}$ The literature on closure and reconciliation is vast. See Christopher J. Colvin, “"Brothers and Sisters, Do Not Be Afraid of Me": Trauma, History and the Therapeutic Imagination in the New South Africa' in Katharine Hodgkin and Susannah Radstone (eds), Memory, History, Nation: Contested Pasts (Transaction Publishers, 2006); John Borneman, 'Reconciliation after Ethnic Cleansing: Listening, Retribution, Affiliation' (2002) 14 Public Culture 281; Yaacov Bar-Siman-Tov, 'Dialectics between Stable Peace and Reconciliation' in Yaacov Bar-Siman-Tov (ed), From Conflict Resolution to Reconciliation (Oxford University Press, 2004); Brandon Hamber and Richard A. Wilson, 'Symbolic Closure through Memory, Reparation and Revenge in Post-Conflict Societies' (2002) 1 Journal of Human Rights 35; Daniel Philpott, 'An Ethic of Political Reconciliation' (2009) 23 Ethics and Intentional Affairs 389.

${ }^{7}$ Payam Akhavan, 'Justice in the Hague, Peace in the Former Yugoslavia? A Commentary on the United Nations War Crimes Tribunal' (1998) 20 Human Rights Quarterly 737, 766.

${ }^{8}$ Graeme Simpson, Edin Hodžić and Louis Bickford, Looking Back, Looking Forward: Promoting Dialogue through Truth-Seeking in Bosnia and Herzegovina (United Nations Development Programme, 2012).

${ }^{9}$ Diane F. Orentlicher, 'Setting Accounts: The Duty to Prosecute Human Rights Violations of a Prior Regime' (1991) 100 Yale Law Journal 2537.

${ }^{10}$ Jemima Garcia-Godos, 'It's About Trust: Transitional Justice and Accountability in the Search for Peace' in Cecillia Marcela Baillet and Kjetil Mujezinovic Larsen (eds), Promoting Peace through International Law (Oxford University Press, 2015).

${ }^{11}$ Michael Scharf, 'The Case for a Permanent International Truth Commission' (1997) 7 Duke Journal of Comparative and International Law 375, 379; Judith Herman, Trauma and Recovery (Basic Books, 1994$), 1$.

${ }^{12}$ In its report, the Truth and Reconciliation Commission in South Africa affirmed the 'healing potential of storytelling, of revealing the truth before a respectful audience and to an official body'. (TRC, Report of the Truth and Reconciliation Commission (TRC, 1998), vol. 5, ch. 9, para. 6. (TRC Report)) Also see, Akhavan (n7), 766.

${ }^{13}$ Brandon Hamber, 'Does the Truth Heal?' in Nigel Biggar (ed), Burying the Past: Making Peace and Doing Justice after Civil Conflict (Georgetown University Press, 2003).
} 
Over time, these vague expectations have been the subject of more sober and empirically based analysis. ${ }^{14}$ This analysis has mainly focused on two critiques: first, that what is meant by 'truth' is, by no means, self-evident and second, that closure and reconciliation are distinct goals. The argument with regards to the first critique is that truth, or at least its presentation, is subjective. As a result, the version of the truth one is likely to hear, and the contribution this can make to closure and reconciliation, depends on the choices made by those responsible for discovering and disseminating the truth in the first place. These choices concern decisions about what information to look for, who to ask and how to convey what has been discovered. ${ }^{15}$ Equally important is whether the reporting merely describes a past event, what has been called 'factual truth', or conveys a sense of judgment as well, that provides a richer 'moral' 16 or 'psychological truth' ${ }^{17}$ In light of these distinctions, general utterances about the positive relationship between truth and other peacebuilding objectives, like closure or reconciliation, are of little help, unless we know more about the type of truth that is being provided.

The second critique relates to the fact that one should avoid conflating the objective of closure with that of reconciliation. ${ }^{18}$ Closure is concerned with the individual victim and/or their family and is a humanitarian goal. Reconciliation, understood here as the development of meaningful relationships of cooperation between former enemy parties, (usually) focuses on the society at large. ${ }^{19}$ The general population, which reconciliation-promoting measures target, can be reconciled even if the victims or their families have not achieved any closure. ${ }^{20}$ Despite the assumption that there is a linear, positive relationship between truth, closure and reconciliation,

\footnotetext{
${ }^{14}$ James L. Gibson, Overcoming Apartheid: Can Truth Reconcile a Divided Nation? (Russel Sage Foundation, 2004); Simon Robins, 'Challenging the Therapeutic Ethic: A Victim-Centred Evaluation of Transitional Justice Process in Timor-Leste' (2012) 6 International Journal of Transitional Justice 83.

${ }^{15}$ Erin Daly, 'Truth Skepticism: An Inquiry into the Value of Truth in Times of Transition' (2008) 2 International Journal of Transitional Justice 23, 25.

${ }^{16}$ Michael Ignatieff, 'Articles of Faith' (1996) 5 Index of Censorship 110.

${ }^{17}$ Tristram Hunt, 'Whose Truth? Objective Truth and a Challenge of History' (2004) 15 Criminal Law Forum 93, referring to the similar concepts of 'forensic truth' and 'psychological truth'. See also, TRC Report (n12), vol. 1, ch. 5, para. 29.

18 ibid., vol. 1 , ch. 5 , para. 14.

${ }^{19}$ There is a vast literature on the definition of reconciliation. Some authors describe the concept as an outcome, others as a process; some view reconciliation as something that happens on an individual and others on a social level. For a literature review and a justification of the definition proposed here, see Nasia Hadjigeorgiou, Protecting Human Rights and Promoting Peace in Post-Violence Societies (Hart Publishing, 2020), 39-44. For an excellent analysis, see also Erin Daly and Jeremy Sarkin, Reconciliation in Divided Societies: Finding Common Ground (University of Pennsylvania Press, 2007).

${ }^{20}$ Richard A. Wilson, 'Anthropological Studies of National Reconciliation Processes' (2003) 3 Anthropological Theory 367; Fiona C. Ross, 'On Having Voice and Being Heard: Some After-effects of Testifying before the South African Truth and Reconciliation Commission' (2003) 3 Anthropological Theory 325.
} 
the process linking the concepts is unpredictable and changes from person to person. ${ }^{21}$ Further, if telling the truth in a public forum promotes feelings of closure for the individual victim, it does not follow that this process can promote reconciliation for the society at large. Treating victims suffering from PTSD and helping them accept past atrocities committed against them can indeed be aided through truth-telling, as long as this takes place in highly controlled environments by trained psychologists. ${ }^{22}$ Yet, there is little evidence that the crude replication of this process in a court room or when testifying before a truth commission will yield the same results. And even if these are forthcoming for individual victims or their families, it is unclear how they will also manifest within the general population that is merely observing the process from a distance, rather than actively participating in it. Thus, the idea that truth-induced closure on an individual level can help a society 'heal' and reconcile, raises unanswered questions, such as what ailment the society is suffering from and why exactly truth and closure are considered the medicines. ${ }^{23}$

Considering the difficulties in defining the 'truth' and the tenuous relationship between closure and reconciliation, there is value in clarifying the underexplored links between just two of these concepts - namely truth and closure - and setting aside, for now, any possible connections with reconciliation. ${ }^{24}$ To the extent this relationship has been examined, the literature has focused almost exclusively on the contributions of courts and truth commissions. These institutions are believed to promote closure by engaging directly with victim-witnesses and empowering them to share their truth. However, whether truth leads to closure depends, inter alia, on specific procedures being followed, with cross-examination and restrictions in the time a victim is allowed to talk, raising particular difficulties in this regard. ${ }^{25}$ Furthermore, the closure-inducing effects of courts and truth commissions are limited because only a small percentage of victims

\footnotetext{
${ }^{21}$ Brandon Hamber, Dineo Nageng and Gabriel O'Malley, “"Telling It Like It Is...”: Understanding the Trust and Reconciliation Commission from the Perspective of Survivors' (2000) 26 Psychology in Society 18.

${ }^{22}$ Dinka Corkalo et al, 'Neighbors Again? Intercommunity Relations after Ethnic Cleansing' in Eric Stover and Harvey M. Weinstein (eds), My Neighbor, My Enemy: Justice and Community in the Aftermath of Mass Atrocity (Cambridge University Press, 2004); Brandon Hamber, Dealing with Painful Memories and Violent Pasts: Towards a Framework for Contextual Understanding, Berghof Handbook Dialogue Series No 11 (Berghof Foundation, 2015).

${ }^{23}$ Harvey M. Weinstein, 'Editorial Note: The Myth of Closure, the Illusion of Reconciliation: Final Thoughts on Five Years as Co-Editor-in-Chief' (2011) 5 International Journal of Transitional Justice 1.

${ }^{24}$ This is not to argue that closure is a more valuable objective to reconciliation. While both are important, the relationship between truth and reconciliation has been examined to a greater extent than that between truth and closure. The article addresses this gap in the literature by focusing on the latter.

25 James L. Gibson, 'On Legitimacy Theory and the Effectiveness of Truth Commissions' (2009) 72 Law and Contemporary Problems 123; Hamber (n13).
} 
are given the opportunity to tell their truth in such settings. ${ }^{26}$ Thus, the problem is that providing closure to the victims is at best a useful biproduct, rather than the primary objective of these institutions. (For criminal courts, the main objective is to provide a fair trial to the defendant and for truth commissions, it is to convey a historical truth to the population at large.) Therefore, elucidating the relationship between truth and closure solely by examining it through the prism of judicial and truth commission processes, hinders reaching more generalisable conclusions. Institutions like the CMP, which have been designed to bring out the truth and promote closure through different processes, deserve attention in their own right.

Getting to the truth is particularly important to relatives of missing persons, who often suffer from 'ambiguous loss', a form of grief that is unending in the absence of verification of death or certainty that the loved one will return. ${ }^{27}$ For these people, achieving 'closure' means reaching a place

'where the trauma is no longer seen as unfinished business [...] Grief and loss no longer plague the individual consciously or unconsciously, and the victim lives not in a state somewhere between denial and obsession [...The ] loss is to a large degree accepted and incorporated into the functioning of everyday life. ${ }^{28}$

The expectation in the literature is that discovering the truth about what happened to the missing person promotes closure by making the loss less ambiguous and stopping it from being experienced as fresh every day. Providing families with information that allows them to accept that their relative is dead, removes them from their " "no-man's land" of psychological and spiritual existence' and helps them finally start the grieving process. ${ }^{29}$ While finding complete closure, as if the disappearance never occurred, is impossible, discovering the truth can help relatives reach a 'good enough' level of well-being. ${ }^{30}$ The following sections assess whether the work of the CMP has allowed this expectation, which links truth and closure, to materialise.

\section{THE COMMITTEE ON MISSING PERSONS}

\footnotetext{
${ }^{26}$ Lorna McGregor, "International Law as a "Tiered Process": Transitional Justice at the Local, National and International Level' in Kieran McEvoy and Lorna McGregor (eds), Transitional Justice from Below: Grassroots Activism and the Struggle for Change (Hart Publishing, 2008).

${ }^{27}$ Pauline Boss, Ambiguous Loss: Learning to Live with Unresolved Grief (Harvard University Press, 2000); CMP and ICRC, Needs of the Families of Missing Persons in Cyprus (2019) (CMP and ICRC Report), 5-6.

${ }^{28}$ Hamber and Wilson (n6), 37.

${ }^{29}$ Mary Ellen Keough, Tal Simmons and Margaret Samuels, 'Missing Persons in Post-Conflict Settings: Best Practices for Integrating Psychosocial and Scientific Approaches' (2004) 124 Journal of the Royal Society for the Promotion of Health 271, 271.

${ }^{30}$ Ronnie Janoff-Bulman, Shattered Assumptions: Towards a New Psychology of Trauma (Free Press, 1992).
} 
The CMP is both an outcome of, and a response to, the Cyprus conflict. Cypriots are mostly divided between two communities: Greek Cypriots (GC) make up 80\% and Turkish Cypriots (TC) $18 \%$ of the population. ${ }^{31}$ Until 1963 , GC and TC were living relatively non-violently in mixed towns and villages around the island. In 1963-64, inter-communal strife broke out, which resulted in the first missing persons of the conflict, who were overwhelmingly TC. ${ }^{32}$ Relations between the two groups remained strained for the following decade and culminated in 1974, when the Greek dictatorship and GC paramilitaries attempted to overthrow the democratically elected president of the Republic of Cyprus. Immediately after, and claiming to protect TC interests, Turkey invaded the island and continues to this day being in occupation of $36 \%$ of the island's territory. ${ }^{33}$ The violence of 1974 gave rise to the remaining missing persons of the conflict, from both communities. ${ }^{34}$ In total, there are 2002 reported missing persons, $1510 \mathrm{GC}$ and 492 TC..$^{35}$

After 1974, the communities were totally isolated from each other, with TC residing almost exclusively in the north of the island, GC in the south, and the two being separated by an impermeable buffer zone (also known as the Green Line). This changed in 2003 when the first of nine checkpoints opened, allowing the crossing of the Green Line and the interaction of the two groups for the first time since the war and the last disappearances. ${ }^{36}$ Although the Cypriot conflict is non-violent, it also remains unresolved as all attempts to negotiate a comprehensive peace settlement have, so far, failed. On the ground, GC retain control of only part of the internationally recognised Republic of Cyprus. The rest has been declared by TC to be the 'Turkish Republic of Northern Cyprus', a de facto state that has only been recognised by Turkey. ${ }^{37}$

\footnotetext{
${ }^{31}$ Republic of Cyprus Department of Statistics and Research, Census of Population and Agriculture 1960 (Volume III - Demographic Characteristics) (Department of Statistics and Research, 1963). This is the last reliable census of the total Cypriot population.

${ }^{32}$ Paul Sant Cassia, Bodies of Evidence: Burial, Memory and the Recovery of Missing Persons in Cyprus (New York, Berghahn Books, 2005).

${ }^{33}$ Zaim Necatigil, The Cyprus Question and the Turkish Position in International Law (2nd edition edn, Oxford University Press, 1996).

${ }^{34}$ Cassia (n32).

${ }^{35}$ CMP 'Facts and Figures', available at http://www.cmp-cyprus.org/content/facts-and-figures.

${ }^{36}$ UN Secretary-General, Report of the Secretary General on the United Nations Operation in Cyprus, S/2003/572 (United Nations, 27 May 2003).

${ }^{37}$ UNSC Res 541 (18 November 1983).
} 
It is in the context of a frozen conflict that the CMP was created in $1981 .{ }^{38}$ Its very establishment was considered an achievement, as it was negotiated under the auspices of the UN, by the leaders of the two communities, neither of whom recognises the other as legitimate. The rationale for the creation of the CMP was that this humanitarian issue could not wait, thus making it necessary for GC and TC to cooperate in order to locate the missing, or their remains, even in the absence of a comprehensive peace agreement. ${ }^{39}$ Humanitarian considerations notwithstanding, disagreements between the representatives of the two communities left the CMP dormant between 1981 and the early 2000s, with the UN Secretary-General contemplating whether to dissolve it on at least one occasion. ${ }^{40}$ Contrary to all expectations, and at a time when inter-communal relations were at their absolute nadir, in 2004 the CMP became operational and soon after, started locating and identifying missing persons. ${ }^{41}$ Since then, it has exhumed 1188 bodies, and identified 994 missing persons, in almost equal ratios from the two communities. ${ }^{42}$

The CMP is a bicommunal institution, meaning that it is headed and staffed by both GC and TC. ${ }^{43}$ Its mandate is to 'look into cases of persons reported missing' ${ }^{44}$ in Cyprus between 1963 and 1974, 'specifying as appropriate whether they are alive or dead, and in the latter case approximate time of the deaths'. ${ }^{45}$ The Committee's objective, according to its terms of reference, is exclusively a 'humanitarian' one, ${ }^{46}$ namely to inform the missing persons' families of what happened to their relatives. Although this is not explicitly stated in the terms of reference themselves, "the primary objective of the CMP is to return the remains of missing persons to their families in order to arrange for a proper burial and close a long period of anguish and uncertainty. ${ }^{47}$ Its operations are not intended to gather information that could

\footnotetext{
${ }^{38}$ CMP, 'UN Press Release' (22 April 1981), available at http://www.cmp-cyprus.org/press-releases/un-pressrelease.

${ }^{39}$ See, the preamble of UNGA Res 3450 (XXX) (9 December1975), which called for the establishment of the CMP.

${ }^{40} \mathrm{UN}$ Secretary-General, Report of the Secretary-General on the United Nations Operation in Cyprus, S/1996/1016 (United Nations, 10 December 1996), para. 27.

${ }^{41}$ For information on how and why the CMP become operational again see Iosif Kovras and Neophytos Loizides, 'Delaying Truth Recovery for Missing Persons' (2010) 17 Nations and Nationalism 520, 522. Also see, Neophytos Loizides, Designing Peace: Cyprus and Institutional Innovations in Divided Societies (University of Pennsylvania Press, 2016), 157-163.

${ }^{42}$ CMP Facts and Figures (n35).

${ }^{43}$ CMP Terms of Reference (n3), para. 1.

44 ibid., para. 7.

45 ibid., para. 13.

46 ibid., para. 1.

${ }^{47}$ CMP, 'What do we do', available at http://www.cmp-cyprus.org/content/what-we-do.
} 
subsequently be used in criminal investigations or trials, ${ }^{48}$ or for the promotion of reconciliation. ${ }^{49}$

A typical case that the CMP deals with is divided into five stages: ${ }^{50}$ the first involves investigations in order to identify the possible location of a missing person's remains and the second results in the exhumation of these remains by a team of archaeologists. In the third stage, anthropologists assemble the remains that have been discovered and in the fourth, geneticists send samples for DNA testing to designated laboratories. ${ }^{51}$ Finally, when the scientists have confirmed the identity of the missing person, the family is contacted and informed of the outcome. In practice, this involves one or more home visits from a psychologist in order to prepare the relatives for, and announce, the CMP's findings. Following this, there is a visit to the Family Viewing Facility, where the relatives can see the assembled skeleton of the (now officially) deceased person and discuss the identification process with the scientists involved in their case. The remains are then returned to the families for burial, which the Committee offers to pay for, ${ }^{52}$ through funds mostly provided by the EU. ${ }^{53}$

Thus, the CMP operates in a very different manner from courts or truth commissions. ${ }^{54}$ There are three main differences between these truth-seeking institutions. The first is that while only a tiny percentage of the missing persons' relatives will participate in a trial or proceedings of a truth commission, the CMP will ideally have direct contact with relatives of all missing persons (in practice, it reaches out to every family whose relative has been identified). Second, the relatives that become involved in a trial or give testimony to a truth commission, actively participate in the truth-telling process, contrary to family members of the missing in Cyprus, who are only involved in truth-hearing: they are passive recipients, not conduits, of the truth. The final difference is that the audience of courts and truth commissions is the general

\footnotetext{
${ }^{48}$ CMP Terms of Reference (n3), para. 11.

${ }^{49}$ Although the CMP frequently asserts that its operations promote 'the healing of old wounds [which] will in turn favour the overall process of reconciliation between both communities', this was decisively not within its objectives in 1981. (See, CMP What We Do (n47).)

50 ibid.

51 Maria Mikellide, 'Recovery and Identification of Human Remains in Post-conflict Environments: A Comparative Study of the Humanitarian Forensic Programs in Cyprus and Kosovo' (2017) 279 Forensic Science International 33.

${ }^{52}$ Natasa Iakovou and Nadia Kornioti, Missing Persons in Cyprus: Observations from the Past and Recommendations for the Future, PRIO Cyprus Report 7/2019 (PRIO Cyprus Centre, 2019), 34.

${ }^{53}$ CMP, 'Donors', available at http://www.cmp-cyprus.org/content/donors.

${ }^{54}$ For a comparison between the CMP and other truth-seeking institutions, see Loizides (n41), 157-158; Iosif Kovras, Grassroots Activism and the Evolution of Transitional Justice: The Families of the Disappeared (Cambridge University Press, 2017).
} 
population of the post-violence society (or, more cynically, academics and fellow legal practitioners), rather than, or in addition to, the victims themselves. Conversely, the CMP is only tasked with communicating the truth about each missing person to their own family. The relatives receive the remains and a brief forensic report, but none of this is shared more widely, which suggests that the only audience the Committee is interested in reaching and having an impact on, are the family members. This absence of multiple intended audiences means that the Committee does not have to cater to potentially competing interests and can exclusively focus its efforts on achieving closure for the relatives. These differences are not to imply that the CMP is better or worse in terms of promoting closure than other truth-seeking institutions, but that it is different. ${ }^{55}$ These differences are potentially impactful and worth exploring more fully.

\section{METHODOLOGY}

The findings of this article are based on an extensive literature review of the CMP and other truth-seeking institutions, and additional empirical research. The literature review encompasses UN resolutions and reports, publications of the Committee and secondary sources. Among the most useful sources was a 2019 report published by the CMP and the International Committee of the Red Cross (ICRC), which documents the needs of the families of the missing in Cyprus by relying on 170 interviews conducted with GC and TC families, whose relatives' remains have not been returned to them yet. ${ }^{56}$ Many of these findings confirm the conclusions of our own empirical research and are referred to throughout the article.

The empirical research on which this article relies consists of 34 interviews with key stakeholders from both communities, which took place between December 2019 and April 2020. Interviews were held with four employees or ex-employees of the CMP (two from each community), two journalists who have been actively following and reporting on the issue of the missing over the last decades (one from each community) and 28 relatives of missing persons, whose remains have already been identified and returned. 21 of the relatives are GC and seven are TC, reflecting approximately the ratio of missing persons between the two

\footnotetext{
${ }^{55}$ When the CMP was established, there were no plans to also set up a Truth and Reconciliation Commission that would supplement its work. Over the years the creation of such a Commission has been debated by civil society and a provision to this effect was also included in the (Draft) Comprehensive Settlement of the Cyprus Problem (Annan Plan, 31 March 2004), Annex VIII. Yet, its creation remains a distant possibility. See, Achilleas Demetriades, 'The Case for Establishing a Truth Commission for Missing Persons in Cyprus' (2014) 3(1) Cyprus Human Rights Law Review 53.

${ }^{56} \mathrm{CMP}$ and ICRC Report (n27).
} 
communities. Most of the interviews took place with first degree family members - siblings and children - but for some TC who disappeared in 1963, interviews had to be held with their grandchildren. Following initial discussions with a CMP psychologist and missing persons organisations, it was decided not to approach parents of the missing, who are today, if alive, at a very advanced age. Finally, the three heads of the Committee - a GC, a TC and an international member - were asked for, but declined to provide, an interview.

Not all relatives are members of, or feel represented by, the two missing persons organisations in Cyprus. ${ }^{57}$ For this reason, potential interviewees were identified and approached through a range of different channels. The first interviews were arranged through personal contacts ${ }^{58}$ and subsequent ones were set up through introductions from those relatives and journalists who had already spoken to the researchers. Additional contacts were established through the two missing persons organisations, bicommunal NGOs, trade unions and municipalities whose residents have particularly high numbers of missing persons. This diverse selection process resulted in a geographically representative sample of missing persons' relatives: they are approximately equally divided among those residing in towns and villages, with interviews having taken place in five out of the six districts of the island. Admitedly, there was a danger that the relatively small number of interviewees and the data-gathering method that was adopted could result in some confirmation bias. Nevertheless, much of the information provided by the relatives is in line with other studies' conclusions and with the evidence provided by the journalists and CMP employees or ex-employees, which further support the reliability of the data. ${ }^{59}$

Of the 28 family members who were interviewed, 16 were men and 12 were women. All GC interviewees had lost one male adult relative, except one person, who had lost his two underage brothers. Of the GC missing persons discussed in the interviews, five were civilians and the

\footnotetext{
${ }^{57}$ Iakovou and Kornioti (n52), 14. The two organisations are the (GC) Pancyprian Organisation of the Relatives of Undeclared Prisoners and Missing Persons and the (TC) Association of Martyrs' Families and War Veterans. They offer psychological support, while also lobbying for greater mobilisation in finding the missing, but are not actively involved in investigation efforts or in helping the CMP. There is also no cooperation between the GC and TC organisations.

${ }^{58}$ This became possible as, in Cyprus, an estimated one in five persons has a close family member who is a missing person. (Djordje Stefanovic, Neophytos Loizides and Charis Psaltis, 'Attitudes of Victims Towards Transitional Justice: The Case of Cyprus', Conference on 'Referendums and Peace Processes' (University of Cyprus, 26 and 27 October 2016).)

${ }^{59}$ Hasibe Şahoğlu, 'One Step Towards Reconciliation in Cyprus: Perceptions of the "Other" for the Families of Missing Persons' (2021) 10 All Azimuth 23.
} 
remaining 17 were soldiers or reserves. The relatives of all TC interviewees were civilians. Three of the TC interviewees had lost a single relative, while in the remaining cases, there were multiple disappearances of family members, including young children. While all of the GC missing persons whose relatives were interviewed were male, some TC interviewees had also lost their mothers and sisters. Finally, of the 28 relatives who were interviewed, three (all TC) had lost their family members in 1964, while the rest disappeared in 1974; this broadly reflects the overall trend and scale of dissappearances in Cyprus. The CMP has not published a list of the 2002 recorded missing persons and does not announce the names of those it has identified. Broadly speaking however, the demographic trends observed in the interviews match what is known about the missing in Cyprus more generally. ${ }^{60}$

\section{THE CMP THROUGH THE EYES OF THE RELATIVES}

\subsection{The closure-inducing effects of hearing the truth}

According to the interviewees, the CMP made three main closure-inducing contributions: first, it provided confirmation that their family member has passed away, thus allowing the grieving process to begin; second, through the return of the remains, it made it possible for them to bury their relative and third, as a result of the funeral, it created a physical space that relatives could visit in order to mourn. The importance of the Committee's work for the relatives is confirmed by a 2019 study, which focused on those whose relatives' remains have not yet been returned. Its main finding is that the first need of $91 \%$ of the respondents is to receive an answer regarding their loved one's fate and in case their relative is dead, receive the remains so that a proper burial can take place. ${ }^{61}$ This is consistent with needs assessments conducted by the ICRC in other post-violence societies and other secondary literature, according to which, families usually seek, as a priority, information on the fate of their missing relative and the retrieval of the remains, if the person has passed. ${ }^{62}$

The effects of the return process were discussed in positive terms by almost all interviewees, including those who believed, even before the CMP contacted them, that their relative was no longer alive. One interviewee whose brother was last seen injured and unable to move, just

\footnotetext{
${ }^{60}$ For demographic information about the missing, see Cassia (n32); Olga Demetriou, Refugeehood and the Postconflict Subject (State University of New York Press, 2018), 171.

${ }^{61}$ CMP and ICRC Report (n27), 9.

${ }^{62}$ ICRC, Living with Uncertainty: Needs of the Families of Missing Persons in Sri Lanka (ICRC, 2016); ICRC, Needs of the Families of the Missing in Timor Leste (ICRC, 2010); Jay D. Aronson, 'The Strengths and Limitations of South Africa's Search for Apartheid-Era Missing Persons' (2011) 5 International Journal of Transitional Justice 262.
} 
moments before a bomb exploded next to him in battle, was certain that he had not survived. Even he however, expressed a sense of relief when the remains were returned because any trace of hope that he was clinging on to could finally be extinguished, thus allowing him to grieve, without feeling guilty for prematurely having given up on his brother. Another, whose brother had also almost definitely died in battle, admitted that she had been holding a Mnemoseno for him every year, in secret (indicating that she believed he was dead even before being contacted by the CMP) ${ }^{63}$ Although the return of the remains did not add to her conviction of his death, it allowed her to stop the covert performance of the grieving rituals and express her sense of loss in public. The impact of the CMP's announcement on the relatives was summarised by an employee of the Committee, when he explained: 'They finally get closure. People might be certain that their relative is dead, but he only truly dies for them, when you tell them [that the remains have been found].'

For those who had been holding on to some hope that their family member was alive, ${ }^{64}$ the remains' return had an even greater impact: it was the first real confirmation of death, and therefore, their first opportunity to obtain a sense of closure. Interviewees insisted that their sadness and feeling of loss never went away, but at least, with the completion of the CMP's process, a new beginning started for them. In the words of one relative, 'This process led the expectancy to an end. The expectation ended. Now we have a grave, a martyrdom to visit on Bayram holidays, on special days, when we go to the village. That's the new page of our lives.' Further, interviewees reported that the return of the remains promoted closure by finally empowering family members to talk about their loss, both amongst themselves and more broadly. ${ }^{65}$

The way in which the confirmation of death takes place under the CMP's procedures - by showing relatives the assembled skeleton, or whatever is left of it - is also effective in helping them come to terms with their new reality. This point was made by many interviewees who said that before visiting the Family Viewing Facility, they were (irrationally) expecting to face the person they had last seen. What they in fact saw was a powerful image that helped them

\footnotetext{
${ }^{63}$ Mnemoseno is a Christian Orthodox ceremony that commemorates the dead.

${ }^{64} 40 \%$ of those who are still waiting for the return of their relatives' remains express ambiguity over their loved ones' fate. Although the remaining $60 \%$ are doubtful that their missing relative could be alive today, they are reluctant to express this with certainty. (CMP and ICRC Report (n27), 3.)

${ }^{65}$ This was also reported in interviews with missing persons' families in Zimbabwe. (Shari Eppel, "Bones in the Forest" in Matabeleland, Zimbabwe: Exhumations as a Tool for Transformation' (2014) 8 International Journal of Transitional Justice 404.)
} 
process that their loved one would not be returning. One TC, whose grandfather and 83 others were abducted from their homes and transferred by bus to a remote location before being executed, recalled: 'I have never seen [my grandmother] in tears when she was explaining to us what happened during the war. But that day at the CMP office, she cried out loudly, as if my grandfather died that day. [...] Until they found the remains, she was expecting him to return home, as if he went abroad with that bus'.

For others, it was not the return of the remains, or even the DNA test which requires $99.95 \%$ similarity between samples, that offered the real confirmation of death, but recognising specific marks on the bodies, or the possessions of their relatives - their wedding ring, a small cross around their neck, the clothes they were wearing on the day of their disappearance, their car keys, or a brand of cigarettes. One interviewee, whose father had disappeared when she was a baby, said that she could tell that he was a close relative from the bone structure of his face, which was very similar to other family members'; another was persuaded that her father was dead when she was given his golden tooth. A third person was impressed by the fact that the CMP staff showed the family an old injury on the skeleton's arm, but stressed that this had been caused previously, in a manner unrelated to the death. In this respect, the work done by the anthropologists is particularly valuable in creating a sense of certainty and closure.

In addition to the confirmation of death, the return of remains allowed the interviewees to finally bury their family member, a process that is both symbolically important, but also gives rise to a physical space that they can visit when they want to honour or remember their loved one. Thus, a representative depiction of how relatives thought about the funeral ceremony was the following: 'this is a way of paying your respects to the dead person and ensuring that the remains are not just left on a mountain or out in the open.' Another common response was that the funeral granted relief to the whole family, but most importantly, it granted relief to the deceased persons themselves because they received a proper burial and their 'body is no longer damped in a well, on a mountain or a field somewhere'. This idea of the relatives having a sense of closure because they felt that they did their duty and the deceased person's soul is now in peace, has been discussed in other post-violence contexts as well. ${ }^{66} \mathrm{It}$ is in sharp contrast to the state of mind of a Cypriot mother of a missing person whose remains have still not been

\footnotetext{
${ }^{66}$ ICRC, Families of Missing Persons in Nepal: A Study of Their Needs (ICRC, 2009), 9; Clark (n2), 430.
} 
returned, who laments: 'Where can I go visit my son? It affects me so much... So much more than you can imagine... The more time passes, the fresher the wound becomes. ${ }^{67}$

The relatives who commented on the closure-inducing effects of the return process, which was the great majority of interviewees, emphasised the professionalism and compassion exhibited by the CMP staff. They understood that the Committee's task of presenting medical evidence was a technical one, but nevertheless appreciated the humane way in which it was carried out. Some commented that they were shown photographs of the location where the missing person had been found, one recalled that together with the body, she had been given some of the soil that laid on top of him when he had been discovered, ${ }^{68}$ and two GC relatives spoke positively of how a priest was allowed to accompany them to the Family Viewing Facility. Moreover, many were impressed with the genuineness and willingness of the psychologists to offer them any help they needed. In this respect, the experiences of two GC family members are telling. One recalled that even 12 years after his father's identification, when the CMP psychologist passes through his mother's village, she pays a visit and drinks coffee with her, to make sure that she is well. Another explained:

'I feel that the CMP gave us more than I could ever have expected. [...] I used to say "There is no way they can lessen my pain." But they did. It was the way they approached things: they were scientific, professional and humane. The psychologist gave us his personal mobile number and told us to call him for whatever support we needed, even on the weekend. We didn't bother him, of course, but it was quite something to hear that in that moment, when the wound was at its most open.'

In this respect, the interviewees confirmed and substantiated expectations in the literature that finding out the truth about one's missing relative can indeed alleviate the ambiguous loss and allow family members to reach a 'good enough' level of well-being.

\subsection{Mind the gap between the truth and closure}

Even though most interviewees described their experiences with the CMP in positive terms, there was not one relative, or journalist commenting on the Committee, who did not also have serious complaints about the way it operates. Some of these complaints expressly undermined the relatives' ability to reach closure, while the impact of others can only be inferred. The

\footnotetext{
${ }^{67}$ CMP and ICRC Report (n27), 10.

${ }^{68}$ This practice is mentioned in Rory MacLean, Beneath the Carob Trees: The Lost Lives of Cyprus (Armida Publications and Galeri Kültür Yayınları, 2016), 14.
} 
criticisms in question concerned the decades-long delays in the return process, the lack of transparency and the idea that the truth the family members got out of the process, important as it was, was not the (only) truth they were seeking. The first two are complaints about the way truth is delivered, while the third is a critique of the type of truth being delivered.

\subsubsection{The way truth is delivered}

\subsubsection{Delays in the CMP's process}

Families first started receiving remains from the CMP in 2006, some 25 years after it was established. Since then, about half of the missing have been returned, but the Committee has indicated that unless new information becomes available, it will not be able to exhume many more. ${ }^{69}$ This is reflected in its results: while in 2015 alone, 155 persons were identified, the equivalent number in 2019 was three. ${ }^{70}$ The first major negative consequence of past delays therefore, is that they made it much harder to locate the missing persons, because, during this time, memories faded, witnesses who had information about disappearances passed away, or buildings and big infrastructure projects were built on top of suspected burial sites. ${ }^{71}$ It is almost certain that many families will not receive the remains of their relatives, thus leaving them altogether unable to experience the closure promised by the CMP.

However, these delays have also undermined a sense of closure among some interviewees whose relatives' remains have been returned. This is first and foremost because many family members, mainly parents but now also increasingly siblings and spouses, are dying without having found out what happened to their loved ones. Among the starkest illustrations of this failure of the CMP is the inscription on the tombstone of the wife of a missing person that reads: 'If you find my husband, please bury him next to me.' ${ }^{72}$ Another is the typical complaint of a sister of a missing person, who recalled that 'My mother died and, on her deathbed, she would say that not a single person turned up to tell us something [about what happened to him.]' Relatedly, many interviewees believed that the lack of urgency exhibited by the Committee was a sign of disrespect towards the loss they suffered and the difficulties they were still facing. Thus, one missing person felt bitter that she had been told by friends who had

\footnotetext{
${ }^{69}$ In-Cyprus, 'CMP: Results in Identifying Missing Persons Remains Will Not Increase' (6 March 2019), available at https://in-cyprus.philenews.com/cmp-results-in-identifying-missing-persons-remains-will-not-increase/.

${ }^{70} \mathrm{CMP}$ Facts and Figures (n35).

${ }^{71}$ Relatives' complaints about the CMP's delays have also been recorded in Iolanda Jaquemet, 'Fighting Amnesia: Ways to Uncover the Truth About Lebanon's Missing' (2009) 3 International Journal of Transitional Justice 69, 81.

${ }^{72}$ MacLean (n68), 14.
} 
connections within the CMP that her brother had been identified, two months before this was formally announced to the whole family. Others suggested, angrily in some cases, that the Committee should have been staffed by the relatives of the missing themselves, because they are the only ones who can understand what the families are going through. They believed that for everyone else, this was just politics or a job and if the Committee truly cared about implementing its humanitarian objective, there would have been no delays in the first place. ${ }^{73}$ Thus, the delays caused some relatives to feel bitter because they perceived them as evidence of the CMP's inability or unwillingness to treat their need for closure as urgent.

An additional way in which the delays undermined closure for some interviewees, concerns the timing of when psychological assistance became available to them. Since the job of CMP psychologists is to inform the relatives that the remains have been found, they have no contact with the families of those who have still not been identified. This arrangement, coupled with the delays, suggests that when family members finally talk to the psychologist for the first time, they have been dealing with ambiguous loss, without the necessary support, for decades. This has been acknowledged as a problem by the Committee itself, which concluded in its 2019 report that $53 \%$ of those whose relatives have not yet been identified, are facing ongoing psychological and psychosocial difficulties (brought about through an absence of closure). ${ }^{74}$ Relatives tend to handle these through medication or by turning to alcohol, but rarely talk about them, whether in public or with other family members. ${ }^{75}$ Interviewees highlighted the failure of the Committee to offer psychological support during the years it was needed the most in bitter language. Thus, when asked whether she achieved closure upon the return of her brother's remains and to assess the psychologist's contribution in this respect, one interviewee replied that this had been compromised by the delay in the CMP's response: 'Sure, they offered psychological help, but what was I going to do with it, 40 years later?'

Finally, delays undermined the Committee's potentially closure-inducing effect because, in many cases, families had discovered the truth about what happened to their loved one independently and long before the CMP reached the same conclusion. For some interviewees, the Committee still contributed to a feeling of closure, albeit to a lesser extent, because the

\footnotetext{
${ }^{73}$ The sense that the politics of the frozen conflict unduly impact the workings of the CMP was also acknowledged by the Committee employees or ex-employees who were interviewed.

${ }^{74} \mathrm{CMP}$ and ICRC Report (n27), 3.

75 ibid, 16.
} 
return of the remains supplemented the story they already knew. Others however, felt that the CMP had failed in its truth-seeking mandate altogether. Instances in which the families discovered the truth on their own were relatively common in both communities. ${ }^{76}$ One GC woman explained that she became aware of what happened to her 'missing' father as soon as the checkpoints opened in 2003, seven years before the CMP returned his remains. She and her husband started their own investigations that revealed why he had been killed and where the body was found, and were ultimately able to meet one of his three murderers and 'see the remorse in his eyes, that he was dead inside'. Another GC met his father's murderer and obtained information about the disappearance, through the help of a GC mafia boss who had connections with TC criminals. Finally, a TC interviewee explained that a contact brought him in touch with a GC who claimed was driving past when he witnessed his father's murder. The informant was able to point exactly to where the body was located, information that the interviewee used to start the digging process on his own (which was subsequently completed by the CMP). The detail that the informant was able to recollect (including the number of bullets that hit each body) led the interviewee to suspect, although this has never been confirmed, that he was, in fact, talking to his father's murderer and not an innocent passer-by.

Despite these interviewees' very different experiences, their stories have three characteristics in common. The first is that for them, the truth they were subsequently told by the CMP was of little value; they had already reached closure, to the extent they could, when they discovered the information on their own. Any further actions of the Committee were, in their eyes, mostly obsolete. The second, which becomes relevant to the discussion that follows, is that all three discovered a very different type of truth than the one the CMP subsequently provided. Not only did they find out who the alleged murderers were, but they also spoke to them and obtained information that other relatives, who went through the proper CMP channels, lament never having received. Finally, the discrepancy between when the relatives and when the Committee discovered the truth, left all three (and others who were interviewed) wondering how hard the CMP was working to achieve its objectives and to what extent it was prioritising the relatives' closure. ${ }^{77}$ This was a sentiment shared by both of the journalists who were interviewed. The

\footnotetext{
${ }^{76}$ This became possible because of the small size of Cyprus and its population, as well as the fact that many killings took place in villages, where witnesses remembered exactly how many people were buried, where and often, even their names. (Jaquemet (n71), 81.)

77 This sentiment was shared by another missing person's relative, interviewed in the late 1990s. (Cassia (n32), 199.)
} 
TC journalist, who has been instrumental in uncovering information for tens of GC and TC missing persons, commented that

'they [the CMP] receive millions of euros in funding in their annual budget from the European Parliament, they have professional investigators, they have photographers, they have cars, they have offices. I have nothing. I have just me and my readers who work voluntarily. And, yet, I have been the one giving them a lot of the information, which is sometimes left there for ages and not evaluated. Some of the witnesses who showed possible burial sites have even passed away, while waiting for the CMP to evaluate their information.'

Echoing her frustration, the GC journalist added: 'If you give me a year, I'm telling you, I'll find half of those who have not been located yet. They don't need to do anything else, the evidence is there. There is no will. So, they can't find a way.'

\subsubsection{Lack of transparency in the CMP's process}

The second complaint voiced in the interviews concerns the lack of transparency in the Committee's proceedings and specifically, the fact that the relatives received no updates during the years, about how the investigations were progressing. ${ }^{78}$ For the return process to be truly humanitarian in its impact, the CMP must keep the families informed about its work, constraints, chances of success, and the probability of finding relatives alive or of identifying and recovering their remains. ${ }^{79}$ When $91 \%$ of missing persons' families stated that their first need is to have an answer about their loved one's fate, this explicitly included receiving updates and feedback about their individual cases. ${ }^{80}$ Yet, this is precisely what the CMP has not been providing over the years. In the words of one interviewee,

'we learn of the activities of the Committee from the press. We will learn about a meeting after it is over. [...] We cannot find the answers to questions like what stage [the investigations] are in, what they are doing, where they are having difficulties, and where we can contribute because they don't have a connection with us.'

This complaint was made by several interviewees, some of whom ultimately concluded that the CMP was instrumental in promoting a sense of closure for them. This suggests that while

\footnotetext{
${ }^{78}$ This is partly due to the CMP's Terms of Reference (n3), para. 9, which state that 'The Committee's entire proceedings and findings will be strictly confidential.'

${ }^{79}$ Crettol et al (n2), 600 .

${ }^{80} \mathrm{CMP}$ and ICRC Report (n27), 3.
} 
many wished for greater transparency, the lack thereof did not necessarily prevent the Committee from achieving its humanitarian objective. Nevertheless, others argued that the CMP's opaque practices undermined its ability to promote closure in one of three distinct ways. First, the lack of transparency and communication left many feeling bitter and disrespected in the belief that the CMP exploited their pain in public, yet ignored them in private by neglecting to provide information about the progress of individual investigations. ${ }^{81}$ The sense of being used by the Committee made these interviewees less willing to accept as truthful the information that was ultimately provided by it.

Second, interviewees pointed out that in the early years after the disappearances, no one talked about them, thus leaving potentially helpful information hidden. By the time people started opening up and different accounts of a single event were compared and confirmed, the CMP had already isolated itself and hindered the flow of information that could have led to earlier discoveries. As a matter of fact, therefore, the lack of transparency contributed to the Committee's delays and consequent lack of closure. Finally, the CMP's opaque practices made it harder for some interviewees to deal with their ambiguous loss. Especially in the 1980s and 1990s, when the Committee was entirely uncontactable, rumours about the whereabouts of the (then believed alive) missing persons were rampant. ${ }^{82}$ Of the $21 \mathrm{GC}$ relatives that were interviewed, eight reported that over the years, they had received allegedly credible, but ultimately untrue, information from third parties about their relative's whereabouts, often upon payment. Receiving confusing or contradictory information was identified as one of the main difficulties they faced, by $51 \%$ of those interviewed for the CMP's 2019 report. ${ }^{83}$ Had the Committee been regularly updating the relatives about the progress of its investigations, much of this heartache could have been prevented.

The final negative consequence of the CMP's lack of transparency is that it created perceptions among interviewees that they were being treated differently depending on their political affiliations. One person complained that others brought a coroner with them to the Family Viewing Facility, a right that had not been granted to his own family. Another claimed that the Committee spent a lot more time and resources looking for some relatives than others and a third wondered how the CMP prioritises its investigations. In most cases, there is a reasonable

\footnotetext{
${ }^{81}$ Examples of this exploitation are also listed in Cassia (n32), 61.

82 ibid., 62-63.

${ }^{83}$ CMP and ICRC Report (n27), 9.
} 
explanation as to why things were done in a particular way, but the lack of transparency led some interviewees to conclude that the Committee was perpetrating additional injustices against them. Among those who complained of less favourable treatment, almost everyone mentioned that some families received more benefits (in the form of financial assistance or job opportunities) than others. Many considered this to be their most serious complaint against the CMP yet had no understanding of the fact that it was never within the Committee's mandate to provide such benefits. Rather, it was other institutions, within the Republic of Cyprus or the 'Turkish Republic of Northern Cyprus' respectively, that were responsible for this. ${ }^{84}$ The failure of the Committee to communicate its mandate and key facts about itself to the relatives, is reflected in the words of a man who has already received his father's remains (and, theoretically, should have been familiar with the CMP's processes and objectives): 'I don't properly know what the CMP is. I don't even know when it started [operating]. So, is this not a recent initiative?' It is therefore, plausible that the confusion the Committee's opague practices created and the resulting feelings among relatives that they were being cheated by the very organisation intended to help them, had the opposite effect of promoting closure.

One concern about sharing (too much) information with the relatives about the investigations is that this can raise expectations and ultimately lead to disappointment, if the search is delayed or, for whatever reason, is unsuccessful. ${ }^{85}$ While it is true that full transparency might in some cases be counter-productive, there are steps that can be adopted in order to strike a balance between informing and protecting the families. For instance, the CMP can, even now, provide basic information about the technical parts of the process, such as what an exhumation or a DNA match is, what exactly the Committee's mandate is and what the considerations that cause certain cases to be prioritised over others are. In turn, this information will demystify the process for the relatives, prepare them for what they should realistically expect and, by being forthcoming about the procedures that are followed, pre-emptively respond to criticisms about favouritism.

Another strategy that can encourage transparency, while protecting the most vulnerable relatives (like very elderly parents) is to ask families whether they want to designate a

\footnotetext{
${ }^{84}$ For a summary of these institutions' responsibilities, see Iakovou and Kornioti (n52).

${ }^{85}$ Report on the Workshop 'Mechanisms for Missing Persons: Clarifying the Fate and Supporting Families' (1617 October 2019, Cyprus), available at https://shop.icrc.org/mechanisms-for-missing-persons-clarifying-the-fateand-supporting-families-pdf-en, 10 (CMP Workshop Report).
} 
representative to receive regular updates about any progress, or lack thereof. This person will then have enough information to gradually start preparing other family members for the psychologist's visit. This approach was informally adopted by some interviewees' families with positive reported results. Finally, the CMP could promote better communication by simply informing families that they can reach out to it with any questions they might have. This will empower relatives by giving them access to knowledge about the progress of the investigations and make them feel respected, without overloading them with too much information. A Committee employee stated during his interview that this is already happening and if the CMP is contacted with questions by a family member, it will share any information it has. ${ }^{86} \mathrm{In}$ practice though, the right to ask for details has never been communicated to the relatives, is not well known among them and is only exercised by those few who have unilaterally demanded access to these.

\subsubsection{The type of truth that is being delivered}

An additional finding of the study concerns the type of truth that the CMP delivers and the extent to which this contributes to feelings of closure. According to its terms of reference, the Committee can determine only whether the missing person is dead or alive, and in the former case (which are, in fact, all cases), return the remains and estimate the time of death. ${ }^{87}$ In practice, the CMP provides more detail than this by sharing brief information, when available, about the period between the times of disappearance and death. In some cases, although not all, the Committee also explains to the families how it obtained the evidence that led to the exhumation of the remains, but never discloses the names of alleged perpetrators or informants. The bare truth that the CMP delivers has left about half of the interviewees feeling underwhelmed. More conductive to a sense of closure, they said, would have been the delivery of more factual, but also psychological truth.

\footnotetext{
${ }^{86}$ This was not always the case. One GC interviewee recalled that in the $1990 \mathrm{~s}$, he was denied access to informarion about the progress of investigations relating to his father's disappearance. The CMP was only persuaded to hand over the information when the interviewee complained to the Attorney-General of the Republic of Cyprus and threatened to complain about this lack of transparency to the media.

${ }^{87}$ In fact, this is technically an expanded definition of the type of truth that the CMP can deliver. Its Terms of Reference (n3), para. 13 state that 'The committee will use its best efforts to draw up comprehensive lists of missing persons of both communities, specifying as appropriate whether they are alive or dead, and in the latter case approximate time of the deaths' and do not mention the exhumation of remains at all. The exhumation and return of remains is something that gradually developed as part of the CMP's mandate when it became operational in the 2000s. (Grażyna Baranowska, 'Advances and Progress in the Obligations to Return the Remains of Missing and Forcibly Disappeared Persons' (2017) 99(2) International Review of the Red Cross 709, 730-731.)
} 
Although some interviewees had unrealistic expectations about the truth that the CMP could deliver ('I want to know everything, every hour, every second of my dad's last day'), others were left with reasonable, yet unanswered, questions, like whether their relative had been tortured, raped or taken as a prisoner of war before being killed. ${ }^{88}$ One GC interviewee, who is among the applicants in the ECtHR case Varnava and Others $v$ Turkey, insisted that providing the truth to a much greater extent than the CMP was doing, not only satisfied a human need, but was also a legal obligation. ${ }^{89}$ The response to this is that the CMP is limited by its terms of reference to 'not attempt to attribute responsibility for the deaths of any missing persons or make findings as to the cause of such deaths. ${ }^{90}$ Yet, while the terms of reference are indeed restrictive, it is possible for the Committee to act within its mandate, while providing additional information about a person's disappearance (for example, it is not prevented from disclosing who $\mathrm{s} /$ he was with, where s/he was taken, how long s/he was held before the estimated time of death etc).

It is regreatable that the Committee is not generally sharing this intelligence because accessing only the limited truth it provides has hindered some interviewees from reaching closure. In the words of one relative, 'people have found their loved ones, but still with no answer to the question of how this happened. Therefore, individuals are still unbalanced. We need to find satisfactory answers to heal.' It is these unsatisfactory answers that encouraged some interviewees to continue with their own investigations, even after receiving their relatives' remains - had they achieved closure with the information they had been provided, such efforts would have naturally stopped. Of the 28 relatives who were interviewed, only nine said that the story they shared about their family member's disappearance had been exclusively provided

\footnotetext{
${ }^{88}$ With rumours circulating about what happened and in the absence of definitive information that confirms or denies them, relatives might continue experiencing ambiguousness, even after they have received the remains. ${ }^{89}$ ECtHR, Varnava and Others v Turkey, App no 16064/90, 18 September 2009; ECtHR, Cyprus v Turkey, App no 25781/94, 10 May 2001, para. 135. The ECtHR held that investigations and possible prosecutions in cases of missing persons are necessary requirements to satisfy the deceased's procedural right to life and the relatives' right to be free from torture. The argument that Turkey had a responsibility to investigate the fate of their relatives to a much greater extent than the CMP had done, has also been made in a number of admissibility cases to the ECtHR by applicants who have already gone through the CMP process (eg, ECtHR, Charalambous and Others v Turkey, App no 46744/07, 3 April 2012). Also see Nikolas Kyriakou, 'Enforced Disappearances in Cyprus: Problems and Prospects of the Case Law of the European Court of Human Rights' (2011) 2 European Human Rights Law Review 190.

${ }^{90}$ CMP Terms of Reference (n3), para. 11.
} 
by the CMP. Seven had supplemented the Committee's story with their own investigations and 11 had discovered the truth entirely independently from the Committee. ${ }^{91}$

In addition to relatives complaining that the CMP provided a truncated version of factual truth, some were also disappointed by the fact that it made no attempt to engage with psychological truth, by answering questions that are central to the promotion of closure, like 'Why did this happen?' and 'Why to him?'. ${ }^{92}$ One family member partly justified the Committee's decision not to engage in such discussions when he suggested that "No matter what they tell you, that "why?" will never really go away.' While that might be true, there are steps that the Committee could have taken in order to provide some sense of psychological truth to those who needed it. For example, in an exceptional case, one of the GC interviewees whose brother had died in battle, explained how he met, through the CMP, the Turkish army commander who had ordered the attack that caused his brother's death. The interviewee recalled that this was an important moment for him because it allowed him to discuss something that shaped his own life, with a person who saw it from the other perspective. Such meetings would not be possible, or even desirable, in every case - they would depend on the relative's and the perpetrator's state of mind - but at least in some cases, they would be able to contribute to a sense of closure. At the same time, while logistically difficult, the relatively low number of missing persons in Cyprus suggests that they are not impossible to arrange. Yet despite the positive potential of such meetings, especially in the presence of the qualified psychologists employed by the Committee, and although this particular interaction helped both participants, no other interviewees mentioned having been given such an opportunity by the CMP.

There are other, less logistically difficult and psychologically strenuous ways, in which the Committee could have promoted closure among the relatives. Several interviewees mentioned that when they discovered where their family member had died, they felt the need to visit the place. Some did this, sometimes with the help of witnesses they had tracked down or through connections with CMP staff that were acting in their personal capacity. In other cases, however, the terrain is difficult to navigate and the Committee's help in reaching the particular location is necessary. While both relatives and CMP staff mentioned that a visit to such locations would

\footnotetext{
${ }^{91}$ Interviewees found additional information about their relatives' disappearance in books, films or documentaries, from witnesses they had personally tracked down, journalists who had been following their case for years, the perpetrators themselves and, in one case, a private investigator.

92 This dichotomy between the 'truth' provided by an institution and the 'truth' which the relatives expect has also been noted elsewhere. (Robins (n14).)
} 
be something that could be arranged, it is not an idea that has been implemented to date. Finally, in 2018, 'Together we Can', an organisation representing relatives of missing persons from both communities, organised an event, attended by the three CMP members, in which relatives shared and discussed their experiences. The event was considered a success with one interviewee who participated describing it as having 'transformative potential'. Although the Committee pledged to repeat the event, this has not happened to date and no plans for such an event exist in the near future. Yet, in the absence of a published list of missing/deceased persons, which is also indicative of the lack of transparency that characterises the committee's work, if such an event was organised without the CMP's logistical support, it would have a limited reach among the relatives.

Thus, closure could have been promoted to a greater extent if the Committee defined 'truth' in broader terms, through the prism of its humanitarian mandate. Even under its restrictive terms of reference, this would have encouaraged it to disclose more factual information to the relatives and helped them make peace with what happened to their loved ones. Perhaps more crucially, it would have pushed it to adopt concrete actions that promoted psychological truth, rather than merely adopt rhetoric to this effect. ${ }^{93}$

\section{CONCLUSION}

An assessment of the CMP is valuable, not only because it is important for Cyprus and other post-violence societies, ${ }^{94}$ but also because it teaches more general lessons about the relationship between truth and closure. In terms of the lessons learned, the CMP appears to have the tools to promote closure to a greater extent than courts or truth commissions. Its mandate is exclusively and explicitly a humanitarian one, with closure for the relatives being its ultimate goal, rather than simply a means to promoting the end of reconciliation. Moreover, the psychologists it employs can potentially have one-to-one contact with the relatives of all missing persons, which is not usually the case with other truth-seeking institutions. To a certain extent, these characteristics of the CMP - which have affected the way in which it has been designed and is operating - have borne fruit. The Committee promoted closure among the interviewees by providing confirmation that their family member has passed away, making it possible for them to bury their loved one and creating a physical space that they can visit in

\footnotetext{
${ }^{93}$ For an example of this rhetoric, see 'CMP Documentary', available at http://www.cmp-cyprus.org/mediagallery/detail/121/266.

${ }^{94}$ CMP Workshop Report (n85).
} 
order to mourn. The words of one relative, broadly reflective of others' views, are the greatest accolade to the Committee: 'I used to be among those who said "Rather than being told that they found him and he is dead, better not to hear anything from them and keep on hoping." Now [that I have gone through the CMP process], I wish to all the relatives of the missing, that their family members are found.'

At the same time, interviewees insisted that closure could be promoted to a greater extent if changes took place, both in how they CMP delivers the truth and in the type of truth it delivers. It might be too late for the Committee to address delays in its procedures, but it can still take meaningful steps to improve its transparency by regularly communicating with families whose relatives have not yet been identified. Moreover, while the Committee's terms of reference might be restrictive, there is still room to deliver more factual truth to the relatives about what happened to their loved ones between the times of disappearance and death. Perhaps more importantly, there is nothing stopping the CMP from implementing activities to deliver greater psychological truth. These activities might not be expressly provided by the CMP's terms of reference, but they are entirely in line with its humanitarian mandate. In any case, the Committee has already proven that it can act unilaterally to innovate and improve its procedures, when the political will to do so is present. ${ }^{95}$

The assessment of the CMP also gives rise to two additional conclusions about the relationship between truth and closure more generally. First and foremost, the interviews confirmed that helping victims or their families achieve closure is an important humanitarian objective in and of itself, even in the absence of more ambitious plans for the promotion of reconciliation. Second, they suggested that the relationship between truth and closure is not always positive or to be taken for granted. In some cases, when delivered clumsily, or too late, the truth had no impact on closure; similar consequences sometimes followed when only part of it was delivered. Nevertheless, for those who thought that truth was delivered in a professional, transparent, humane and thoughtful manner, its impact on closure, on stopping the ambiguous loss and changing the relatives' lives for the better, was monumental. This suggests that policy makers must pay close attention to the design and implementation of truth-seeking bodies with

\footnotetext{
${ }^{95}$ One of the interviewees was among the first to receive a relative's remains. He identified several shortcomings of the process and informed the CMP of these. When the next set of remains was returned to the families a month later, his recommendations had already been implemented (such as the idea that the CMP, and not the relatives, should pay for the funeral).
} 
a humanitarian mandate. They have a responsibility to identify the strengths and weaknesses of institutions and approaches when assessing their transplantation potential. Finally, they must remain vigilant to ensure that, with the passage of time, the procedures they adopted during the design and early implementation stages continue meeting their stated objectives. 